\title{
Penilaian Daya Tarik Obyek Wisata: 20 Obyek Wisata di Ponorogo, Indonesia
}

\author{
*Rendy Bayu Aditya, Chrismonica Ayudiah \\ Perencanaan Wilayah dan Kota, Departemen Teknik Arsitektur dan Perencanaan, Fakultas Teknik, Universitas Gadjah Mada \\ * adityarb@ugm.ac.id
}

\begin{tabular}{l} 
INFO ARTIKEL \\
\hline Riwayat Artikel: \\
Diterima: 18-07-2020 \\
Disetujui: 25-08-2020
\end{tabular}

\section{Kata Kunci:}

Atraksi wisata

Obyek wisata

Penilaian daya tarik

\begin{abstract}
ABSTRAK
Abstrak: Artikel ini bertujuan untuk menilai daya tarik obyek wisata dan mengungkap manfaat-manfaat yang didapatkan dari penilaian daya tarik wisata. Riset yang dilaporkan melalui artikel ini mengambil contoh kasus 20 obyek wisata yang ada di Kabupaten Ponorogo. Metode yang digunakan adalah analisis multikriteria dengan penilaian sederhana biner. Terdapat 4 komponen daya tarik yang digunakan meliputi Atraksi, Aksesibilitas, Amenitas, dan Penyokong. Keempat komponen tersebut diturunkan ke dalam 12 atribut meliputi: (1) Rating atraksi; (2) Jarak dari pusat kota; (3) Kondisi jalan; (4) Transportasi umum; (5) Tempat parkir; (6) Akomodasi terdekat; (7) Tempat ibadah; (8) Warung makan / restoran; (9) Toilet; (10) Informasi / ulasan; (11) Penunjuk / penanda; (12) Peta. Temuan riset menunjukkan bahwa dari 20 obyek wisata yang diteliti, 10 obyek wisata masih masuk dalam kategori dengan daya tarik agak rendah, rendah, dan sangat rendah. Sisanya masuk dalam kategori daya tarik sedang, agak tinggi, tinggi, dan sangat tinggi. Selanjutnya, manfaat dari penilaian daya tarik tersebut antara lain: berhasil mengidentifikasi peringkat dan kategori daya tarik obyek sebagai dasar perumusan prioritas pengembangan serta mengidentifikasi kelemahan masing-masing atribut dari setiap obyek wisata yang dapat digunakan sebagai dasar perumusan program dan kegiatan yang tepat sasaran dan tepat guna.
\end{abstract}

\begin{abstract}
This article aims to demonstrate the result of tourism destinations attractiveness assessment and reveal the benefits obtained from the assessment. This article takes the case of 20 tourism destinations in Ponorogo Regency. The research employs a multi-criteria analysis with a simple binary scoring system. There are 4 components of attraction used including Attractions, Accessibility, Amenities, and Ancillary. The four components are derived into 12 attributes including: (1) Attraction rating; (2) Distance from city center; (3) Road conditions; (4) Public transportation; (5) Parking area; (6) Closest accommodation; (7) Places of worship; (8) Food stalls / restaurants; (9) Toilets; (10) Information / reviews of destinations; (11) Signages; (12) Maps. The results show that of the 20 attractions studied, 10 are still in the category of slightly low, low, and very low attractiveness. The rest are in the category of medium, slightly high, high and very high. Furthermore, the benefits of attractiveness assessment include: first, it successfully identifies the ranking and attractiveness status of tourism destinations, thus it can be used as a foundation for formulating development priorities. Secondly, it also identifies the weaknesses of each attribute of each tourism destination which could be used as a basis for making effective tourism activities programs.
\end{abstract}

\section{A. LATAR BELAKANG}

Banyak daerah yang berupaya mengembangkan perekonomiannya melalui sektor pariwisata. Karakter geografi yang unik, keindahan alam, peninggalan sejarah, hingga atraksi-atraksi buatan manusia, menjadi sumberdaya pariwisata yang terus dikembangkan dan dipromosikan. Daerah tersebut berlomba-lomba untuk memasarkan keunggulan obyek wisata yang dimilikinya. Kondisi ini menciptakan kompetisi antar obyek wisata baik lokal, nasional, bahkan internasional [1-4]. Untuk siap berkompetisi maka obyek wisata perlu memiliki keunggulan [4-7]. Keunggulan obyek wisata dalam berkompetisi dapat didekati dengan konsep yang dikenal sebagai daya tarik obyek wisata (tourism attractiveness) $[1,3,8,9]$. Semakin tinggi daya tarik obyek wisata, maka semakin unggul pula obyek wisata tersebut dalam berkompetisi [3]. Juga, semakin tinggi daya tarik sebuah obyek wisata, semakin banyak pula jumlah turis yang mendatangi obyek wisata tersebut [10-13], sehingga berdampak pada bergeraknya roda ekonomi sebuah wilayah.

Riset ini berargumentasi bahwa keunggulan obyek wisata dapat didekati dengan menilai daya tarik wisata tersebut. Seperti yang dijelaskan oleh beberapa peneliti bahwa adanya daya tarik wisata merupakan salah satu 
modal dasar pendorong munculnya kegiatan wisata $[8,14,15]$. Bahkan banyak peneliti berpendapat bahwa daya tarik wisata memiliki peran dalam mempengaruhi keputusan para turis untuk mengunjungi obyek wisata [11-13,16]. Artinya, menilai daya tarik wisata dapat memberikan pemahaman sejauh mana obyek wisata tersebut dapat menarik wisatawan untuk datang. Selain itu, penilaian daya tarik obyek wisata memberikan pengetahuan tentang kondisi dan kinerja aktual dari sumberdaya yang dimiliki obyek wisata tersebut $[1,9,12]$, sehingga strategi-strategi untuk meningkatkan kinerja dan fasilitas obyek wisata dapat dilakukan secara tepat sasaran dan tepat guna [17].

Berdasarkan latar belakang tersebut, riset ini berusaha menawarkan sebuah kebaruan antara lain: 1). Menilai obyek wisata pada tingkat lokal yang menggunakan beragam tipe obyek wisata; dan di saat yang bersamaan berusaha untuk 2). Mengidentifikasi manfaat-manfaat yang bisa didapatkan dari adanya penilaian daya tarik obyek-obyek wisata di tingkat lokal tersebut.

Berdasarkan pada latar belakang tersebut maka riset ini bertujuan mengisi celah dan menawarkan kebaruan riset di bidang keilmuan pengembangan destinasi wisata dengan mengajukan dua pertanyaan penelitian:

1. Berapa tingkat daya tarik (seberapa menarik) obyek-obyek wisata yang ada di sebuah daerah?

2. Apa manfaat yang didapatkan dari penilaian daya tarik obyek-obyek wisata tersebut?

Untuk menjawab pertanyaan penelitian tersebut, dibutuhkan sebuah kasus empiris. Untuk itu, penelitian ini mengambil Kabupaten Ponorogo beserta 20 obyek wisata yang ada di dalamnya sebagai kasus empiris yang diteliti. Ponorogo terpilih karena memiliki beragam obyek wisata, dengan beragam atraksi, dan sebaran lokasi yang relatif merata yang terwakilkan dalam keduapuluh obyek wisata yang digunakan sebagai kasus penelitian.

\section{B. KAJIAN PUSTAKA}

Kajian pustaka dalam riset ini akan membahas konsep terkait daya tarik obyek wisata dan komponenkomponen yang membentuk daya tarik sebuah obyek wisata. Daya tarik dinilai penting karena merupakan aspek paling utama yang menentukan frekuensi kunjungan wisatawan $[16,18]$. Artinya semakin tinggi daya tarik obyek wisata makan akan semakin tinggi pula kemungkinan kedatangan turis-turis mengunjungi obyek wisata tersebut. Dengan meningkatnya jumlah turis, maka kegiatan ekonomi lokal dapat tetap berjalan dan bahkan berkembang lebih pesat [19].

Dengan berlandaskan pada argumentasi AndradesCaldito, Sánchez-Rivero, \& Pulido-Fernández (2014), kerangka teori yang digunakan dalam penelitian ini berfokus pada penilaian daya tarik dari sudut pandang sumberdaya pariwisata atau pada aspek-aspek yang memberikan keunggulan pada sebuah obyek wisata yang dikenal sebagai endowed dan created resources. Maka, asumsi yang mendasari riset ini adalah semakin tinggi nilai daya tarik sebuah obyek wisata, maka semakin besar kemungkinan turis mengunjungi obyek tersebut. Lebih lanjut, sumberdaya pariwisata yang dimaksud dalam riset ini mengadopsi konsep dari Fletcher, Fyall, Gilbert, \& Wanhill (2013) yang membagi komponen sumberdaya pariwisata pembentuk daya tarik obyek wisata menjadi 4A: Attraction (Atraksi), Accessibility (Aksesibilitas), Amenities (Amenitas), Ancillary (Penyokong). Komponen 4A tersebut menjadi kerangka yang tepat dalam menilai daya tarik obyek wisata sebagaimana telah ditunjukkan dalam riset sebelumnya $[14,18]$. Keempat komponen tersebut akan dijelaskan sebagai berikut.

\section{Atraksi (Attraction)}

Atraksi merupakan sumberdaya yang secara kuat mempengaruhi tingkat daya tarik obyek wisata yang dikenal dengan istilah endowed resources $[1,9,20]$. Atraksi adalah sumberdaya utama yang dimiliki sebuah obyek wisata yang memberikan pengalaman menarik dan unik serta dapat dinikmati oleh turis $[7,17,18,21]$. Atraksi yang ditawarkan obyek wisata bisa sangat beragam dan bergantung pada jenis wisatanya. Sebagai contoh, jenis wisata alam biasanya akan menyajikan atraksi seperti aktivitas fisik, menikmati pemandangan, fotografi, dan berbagai jenis aktivitas luar ruangan lainnya [12,15]. Contoh lainnya adalah wisata peninggalan sejarah yang menawarkan atraksi berupa edukasi sejarah [22]. Satu wilayah (kota, pulau, ataupun negara) dapat memiliki bermacam-macam jenis wisata yang memberikan beragam jenis atraksi. Misalnya saja Bali yang memiliki beraneka ragam wisata seperti wisata alam, sejarah, budaya menyajikan rupa atraksi yang beragam pula [23]. Berdasarkan pada kajian literatur tersebut, atribut atraksi yang diobservasi pada riset ini meliputi kegiatan-kegiatan yang dapat dilakukan turis pada obyek wisata tertentu. Penilaian publik pada obyek wisata tersebut menjadi data yang digunakan untuk mengukur daya tarik obyek wisata dalam konteks komponen atraksi.

\section{Aksesibilitas (Accessibility)}

Aksesibilitas dinilai penting dalam menentukan daya tarik obyek wisata karena meyangkut seberapa mudah dan nyaman turis bergerak untuk mencapai obyek wisata Para peneliti $[14,15,20]$ bahkan menyatakan bahwa sebuah obyek wisata bisa terhambat perkembangannya bila tidak dapat atau sulit diakses oleh turis. Maka sebuah obyek wisata dapat berkembang dan semakin menarik bila kualitas aksesnya semakin baik, nyaman, dan mudah [2,12,24]. Dalam menilai aksesibilitas, terdapat beberapa atribut yang dapat digunakan meliputi jarak atau proximity dari pusat kota [13,24], kualitas jalan $[17,25]$, keberadaan transportasi umum $[16,17,26]$, dan fasilitas area parkir $[14,27,28]$. 
Berikut adalah penjelasan dari masing-masing atribut. Semakin baik kondisi jalan maka semakin nyaman mobilitas turis untuk mencapai tujuan wisatanya wisata $[17,25]$. Selain itu, keberadaan transportasi publik cukup berpengaruh dalam menentukan niat seseorang untuk mengunjungi sebuah obyek wisata. Sebuah obyek wisata yang terjangkau transportasi umum memiliki tingkat kemudahan dan kenyamanan turis dalam mengaksesnya juga semakin baik $[16,17,24,26]$. Selanjutnya, dalam kerangka jangka pendek, keberadaan parkir juga memberikan pengaruh terhadap kualitas aksesibilitas sebuah obyek wisata $[14,27,28]$ terutama saat keberadaan transportasi umum belum mengjangkau lokasi obyek wisata.

\section{Amenitas (Amenity)}

Amenitas adalah aspek yang mendukung kenyamanan para turis saat berada di sebuah lokasi objek wisata [14,29]. Amenitas yang sering dinilai strategis bagi sebuah obyek wisata meliputi restoran $[16,17,20]$ dan akomodasi $[17,20,26]$. Kedua jenis amenitas tersebut memberikan kebutuhan pendukung bagi para turis dalam menikmati atraksi yang ditawarkan oleh obyek wisata. Dalam riset ini, kedua amenitas tersebut diikutsertakan dalam penilaian dengan penambahan dua amenitas lainnya yaitu tempat ibadah dan toilet. Tempat ibadah dan toilet merupakan dua amenitas pendukung obyek wisata yang dapat memberikan kenyamanan dan meningkatkan daya tari bagi para turis pada konteks Indonesia.

\section{Penyokong (Ancillary)}

Komponen terakhir adalah ancillary atau penyokong. Merupakan komponen yang tidak menjadi bagian langsung dari industri pariwisata, akan tetapi cukup vital dalam mendukung kegiatan wisata. Pada riset ini, atribut yang masuk dalam komponen penyokong meliputi: informasi atau ulasan terkait obyek wisata $[9,26]$, penanda arah atau penunjuk jalan [20] dan keberadaan peta baik fisik maupun daring $[7,21]$. Informasi atau ulasan terkait dengan obyek wisata telah menjadi satu kebutuhan turis sebelum merancang perjalanan wisata. Saat ini, ulasan atau informasi obyek wisata secara daring (online) merupakan sala satu sumber informasi paling popular di sektor industri wisata [30]. Maka, dalam riset ini, keberadaan informasi atau ulasan terkait obyek wisata diobservasi melalui dunia maya / internet. Atribut kedua adalah penunjuk atau penanda atau dikenal sebagai signage [20]. Atribut ini berkaitan dengan informasi penyokong yang mungkin diterima turis terkait arah menuju lokasi obyek wisata. Atribut ketiga adalah keberadaan peta yang dapat diakses turis yang juga menyokong informasi lokasi obyek wisata [7,21]. Dalam riset ini, keberadaan peta diobservasi baik secara fisik dan daring. Di era teknologi informasi, peta daring juga menjadi salah satu sumber informasi yang sangat digantungkan para turis [7]. Google Maps menjadi penyedia peta daring yang diobservasi dalam riset ini karena paling populer dalam konteks Indonesia.

\section{DATA DAN METODE}

\section{Metode Analisis dan Data}

Metode yang digunakan dalam riset ini adalah metode penilaian (scoring) dengan mengikutsertakan beragam kriteria (multi-criteria). Tahapan yang dilakukan dalam riset ini adalah sebagai berikut. Pertama, kriteria yang digunakan untuk menilai daya tarik destinasi wisata dikumpulkan berdasarkan pada literatur yang ada. Terkumpulah 4 komponen pendukung daya tarik wisata dengan total 12 atribut penilaian. Berdasarkan pada 12 atribut tersebut pencarian data dilakukan baik data primer maupun sekunder. Setelah itu, penilaian dari masing-masing atribut berdasarkan data yang didapatkan dilakukan dengan menggunakan sistem penilaian biner (o atau 1). Dari hasil penilaian biner tersebut, kategorisasi tingkat daya tarik destinasi wisata dibuat dengan membaginya menjadi 7 kategori daya tarik.

Tabel 1. Komponen, Atribut, dan Sumber Data

\begin{tabular}{ccc}
\hline Komponen Analisis & Atribut Data & Sumber Data \\
\hline Atraksi (attraction) & Jenis-jenis atraksi & Observasi lapangan \\
& & Pencarian digital (internet): media \\
sosial, forum daring, blog \\
Aksesibilitas (accessibility) & Rating atraksi & Rute Google Maps \\
& Jarak dari pusat kota & Observasi lapangan \\
Kualitas jalan & Google Street View \\
& & Data kualitas jalan format SIG \\
& (Bappeda, 2018) \\
& Ketersediaan transportasi & Dinas Perhubungan \\
Tempat parkir & Observasi lapangan \\
& Observasi lapangan \\
& & Pencarian digital (internet): media \\
& sosial, forum daring, blog, Google
\end{tabular}


Amenitas (amenity)

Akomodasi

Penyokong (ancillary)

Penunjuk arah / penanda jalan

Peta
Observasi lapangan

Pencarian digital (internet): media sosial, forum daring, blog, Google Maps

Observasi lapangan

Observasi lapangan

Observasi lapangan

Pencarian digital (internet): media sosial, forum daring, blog

Observasi lapangan Google Maps

Observasi lapangan Google Maps

\section{Tahap 1: Komponen dan Atribut}

Teknik multikriteria adalah teknik analisis yang mengikutsertakan banyak (lebih dari 1) atribut informasi dan data yang diolah dalam satu proses analisis [15]. Prinsip multi-krietria menjadi wajib dalam menilai daya tarik karena unsur-unsur pembentuk daya tarik obyek wisata cukup kompleks [31] dan tersusun atas banyak komponen dan atribut [29]. Mengacu pada literatur, riset ini merumuskan kriteria dari komponen $4 \mathrm{~A}$ [21] beserta atribut-atribut turunanya dalam menilai daya tarik obyek wisata sebagaimana telah dijelaskan dalam kajian teori, maka didapatkanlah 12 atribut data. Kedua belas atribut data tersebut menggunakan sumber data yang beragam baik primer maupun sekunder, meliputi: observasi lapangan, pencarian di internet melalui media sosial dan forum-forum wisata, penggunaan rating Google, Google Earth, Google Map, hingga data sekunder yang berasal dari dinas terkait. Untuk lebih jelasnya, ragam sumber data untuk tiap atribut disajikan dalam Tabel 1.

\section{Tahap 2: Penilaian Biner}

Pemberian nilai / skor merupakan teknik yang efektif untuk digunakan dalam penelitian pengukuran daya tarik wisata $[12,14,16]$. Pada riset ini, sistem penilaian atribut dibuat sederhana yaitu dengan sistem biner (o dan 1). Alasan paling mendasar dari penggunaan teknik ini adalah agar replikasi metode yang kami gunakan dapat dengan mudah dilakukan oleh para praktisi perencana pembangunan daerah dan pariwisata. Selain itu, riset ini juga ingin menunjukkan bahwa metode sederhana seperti biner (o dan 1) tetap dapat memberikan hasil yang signifikan dalam penilaian daya tarik obyek wisata. Di saat bersamaan juga mampu menjadi teknik dalam identifikasi kelebihan dan kelemahan komponen dan atribut pendukung daya tarik tersebut.

Secara teknis, dalam sistem biner tiap atribut data dibagi menjadi 2 hirarki atau kelas atribut yang masingmasing hirarki atribut tersebut bersandingan dengan nilai o atau 1 [32]. Sebagian besar atribut dalam riset ini perlu dikategorisasi dengan jawaban ada / tidak ada, yang sangat erat dengan karakteristik sistem penilaian biner yang biasanya menggunakan jawaban ya / tidak; ada / tidak ada; atau bila dalam angka menjadi o / 1. Hal ini kembali menguatkan bahwa sistem biner adalah metode yang tepat digunakan dalam riset ini. Tabel 2 menjelaskan sistem penilaian atribut dengan persandingan nilai binernya.

Tabel 2. Sistem Penilaian Atribut

\begin{tabular}{|c|c|c|c|}
\hline $\begin{array}{l}\text { Komponen } \\
\text { Analisis }\end{array}$ & Atribut Data & Hirarki Atribut & $\begin{array}{l}\text { Nilai / } \\
\text { Skor }\end{array}$ \\
\hline \multirow[t]{3}{*}{ Atraksi (attraction) } & Jenis-jenis atraksi & Tidak dinilai & $\mathrm{n} / \mathrm{a}$ \\
\hline & Rating atraksi & $<4$ & $\mathrm{O}$ \\
\hline & & $>=4$ & 1 \\
\hline \multirow{6}{*}{$\begin{array}{l}\text { Aksesibilitas } \\
\text { (accessibility) }\end{array}$} & Jarak dari pusat kota & $>20 \mathrm{~km}$ & $\mathrm{O}$ \\
\hline & & $<=20 \mathrm{~km}$ & 1 \\
\hline & Kualitas jalan & Tanpa perkerasan sama sekali & o \\
\hline & & $\begin{array}{l}\text { Sebagian perkerasan } \\
\text { sepenuhnya perkerasan }\end{array}$ & 1 \\
\hline & Ketersediaan transportasi & Tidak ada & o \\
\hline & umum & Ada & 1 \\
\hline \multirow[t]{6}{*}{ Amenitas (amenity) } & Akomodasi & Tidak ada & o \\
\hline & & Ada & 1 \\
\hline & Tempat ibadah & Tidak ada & o \\
\hline & & Ada & 1 \\
\hline & Warung makan / restoran & Tidak ada & o \\
\hline & Tempat parkir (formal / & $\begin{array}{l}\text { Ada } \\
\text { Tidak ada }\end{array}$ & $\begin{array}{l}1 \\
0\end{array}$ \\
\hline
\end{tabular}




\begin{tabular}{llll} 
& informal) & Ada & 1 \\
& Toilet & Tidak ada & 0 \\
& & Ada & 1 \\
Penyokong & Informasi / ulasan & Tidak ada & 0 \\
(ancillary) & Ada & 1 \\
& Penunjuk arah / penanda & Tidak ada & 0 \\
& jalan & Ada & 1 \\
\hline
\end{tabular}

Sumber: Penulis, 2020

Setelah penilaian biner dilakukan, maka angka yang didapatkan dari masing-masing obyek wisata tersebut dijumlah. Angka total tersebut menunjukkan daya tarik dari obyek wisata berdasarkan pada kinerja (kualitas atau keberadaan) masing-masing atribut. Nilai total maksimal yang bisa didapatkan obyek wisata adalah 12 dan terendah adalah o. Angka total yang didapat selanjutnya akan diurutkan untuk mendapatkan peringkat dan kategori daya tarik masing-masing obyek wisata.

\section{Tahap 3: Kategorisasi Nilai}

Tahap selanjutnya adalah mengkategorisasi tingkat daya tarik wisata berdasarkan pada nilai yang didapatkan dari tiap destinasi wisata. Pada riset ini, kategori yang digunakan sebanyak 7 kategori meliputi: sangat tinggi, tinggi, agak tinggi, sedang, agak rendah, rendah, dan sangat rendah. Penentun nilai untuk setiap kategori dibuat relatif terhadap tiap destinasi wisata sehingga kategorisasi dilakukan setelah nilai daya tarik seluruh destinasi wisata diperoleh. Dengan prinsip tersebut, kategorisasi nilai yang digunakan adalah sebagai berikut: nilai $6=$ sangat rendah, nilai $7=$ rendah, nilai $8=$ agak rendah, nilai $9=$ sedang, nilai $10=$ agak tinggi, nilai $11=$ tinggi, dan nilai $12=$ sangat tinggi.

\section{Konteks Wilayah Penelitian}

Pada penelitian tentang penilaian daya tarik obyek wisata ini, diperlukan kasus berupa wilayah dengan karakteristik memiliki obyek wisata yang beragam baik secara jumlah, sebaran lokasi, maupun jenisnya. Hal ini dilakukan karena penilaian daya tarik wisata ini memiliki sifat memperbandingkan 'nilai / skor' beberapa obyek. Ponorogo digunakan sebagai kasus penelitian berdasarkan 2 alasan. Alasan pertama adalah Kabupaten Ponorogo menjadi bagian dari kawasan strategis pariwisata Jawa Timur yang tergabung dalam kawasan Lingkar Wilis [33]. Alasan kedua yaitu kabupaten ini memiliki beragam obyek wisata yang tersebar di seluruh wilayahnya dengan jumlah total sebanyak 50 obyek [34] dengan kemungkinan pertambahan jumlah obyek setiap tahunnya. Obyek wisata tersebut terdiri dari wisata alam, wisata perkotaan, wisata buatan, hingga wisata sejarah, dengan wisata alam mendominasi ragam wisata yang ada di sana.

Jumlah kasus yang digunakan dalam riset ini berjumlah 20 yang merupakan obyek wisata yang ada di Kabupaten Ponorogo yang dipilih secara acak (random). Dua puluh obyek dinilai cukup mewakili keberadaan total 50 obyek wisata yang ada di Ponorogo. Nama dan lokasi 20 obyek wisata tersebut ditampilkan dalam peta Gambar 2.

Berdasarkan data tahun 2012 - 2015, terlihat bahwa jumlah wisatawan Ponorogo selalu meningkat. Persentase pertumbuhannya juga cukup besar dengan rata-rata pertumbuhan di angka 20\% dalam 4 tahun tersebut (Lihat Tabel 3). Sejalan dengan itu, kontribusi pariwisata terhadap pendapatan daerah Ponorogo mengalami peningkatan dan kontribusi pariwisata merupakan 3 terbesar yang menyumbang hasil retribusinya terhadap pendapatan daerah dibanding dengan 22 sektor lainnya [35]. 


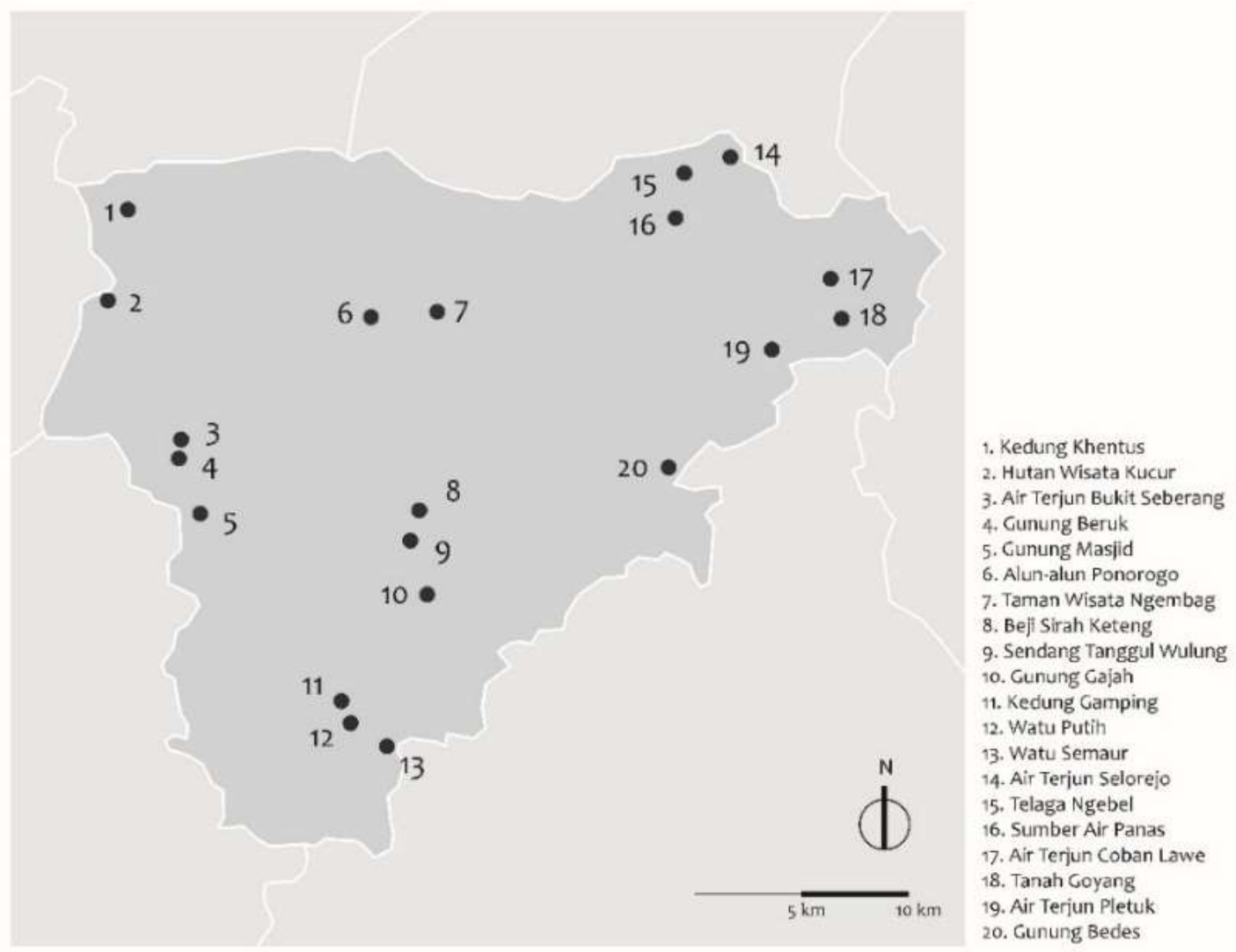

Gambar 1. Peta Persebaran Studi Kasus

Sumber: Analsis, 2020

Tabel 3. Jumlah Wisatawan

\begin{tabular}{ccr}
\hline Tahun & $\begin{array}{c}\text { Jumlah } \\
\text { Wisatawan } \\
\text { (orang) }\end{array}$ & Pertumbuhan (\%) \\
\hline 2012 & 288.548 & \\
2013 & 322.248 & 11.68 \\
2014 & 331.959 & 3.01 \\
2015 & 396.991 & 19.59 \\
\hline
\end{tabular}

Sumber: [35] dengan perhitungan penulis

\section{HASIL DAN PEMBAHASAN}

Pada bab ini dipaparkan 2 bagian pembahasan. Pembahasan pertama adalah hasil koleksi data untuk tiap atribut daya tarik. Pada bagian ini, data dijelaskan dalam bentuk deskriptif (angka dan teks) apa adanya, lalu dinilai di tahap kedua dengan sistem penilaian biner. Pada bagian kedua, hasil dari penggunaan sistem biner dalam menilai obyek daya tarik wisata dipaparkan untuk setiap atributnya. Hasil penilaian rinci ini bertujuan agar kekurangan dan kelemahan masing-masing obyek wisata dapat diidentifikasi sehingga dapat dirumuskan strategi pengembangan yang tepat untuk setiap atribut per obyek wisata.

\section{Data Per Atribut}

\section{Komponen Atraksi (Attraction)}

Kabupaten Ponorogo memiliki banyak jenis wisata yang tersebar di kecamatan-kecamatan Ponorogo. Masing-masing jenis tersebut menawarkan aktivitas wisata yang berbeda-beda. Aktivitas yang dialami oleh wisatawan ini biasanya akan diwujudkan dalam bentuk penilian yang berbeda dari para wisatawan. Penilaian tersebut dikenal pula dengan nama penilaian perseptual. Penilaian perseptual merupakan salah satu jenis penilaian yang cukup baik untuk menggambarkan kepuasan turis atas pengalaman-pengalaman berwisata yang mereka dapatkan dari obyek wisata tertentu $[12,13,36]$. Rincian dari data-data komponen atraksi untuk kedua puluh obyek wisata disajikan dalam Tabel 4.

Riset ini menggunakan penilaian perseptual yang bersumber dari Google Place Rating. Penilaian Google ini cukup mampu menggambarkan penilaian kepuasan perseptual dari wisatawan karena bersifat crowdsourced (atau bersumber / dinilai langsung oleh publik). Angka yang muncul dari Google Rating tersebut lalu dikategorisasi ke dalam nilai biner: o bagi obyek wisata yang mendapatkan rating kurang dari 4 dan 1 bagi obyek wisata yang mendapatkan rating lebih dari 4 . 
Tabel 4. Data Komponen Atraksi

\begin{tabular}{|c|c|c|c|c|}
\hline No & Obyek Wisata & Jenis wisata & Aktivitas utama & Rating Ataksi \\
\hline 1 & Kedung Khentus & Wisata alam & $\begin{array}{l}\text { Aktivitas fisik (eg. renang, tubing), } \\
\text { menikmati keindahan, berfoto (eg. swafoto, } \\
\text { fotografi) }\end{array}$ & $4,3(n=15)$ \\
\hline 2 & Hutan Wisata Kucur & Wisata alam & $\begin{array}{l}\text { Aktivitas fisik (eg. pendakian ringan), } \\
\text { menikmati keindahan, berfoto (eg. swafoto, } \\
\text { fotografi) }\end{array}$ & $4,4(n=19)$ \\
\hline 3 & $\begin{array}{l}\text { Air Terjun Bukit } \\
\text { Seberang }\end{array}$ & Wisata alam & $\begin{array}{l}\text { Aktivitas fisik (eg. pendakian ringan, } \\
\text { renang), menikmati keindahan, berfoto (eg. } \\
\text { swafoto, fotografi) }\end{array}$ & $3,3(n=11)$ \\
\hline 4 & Gunung Beruk & Wisata alam & $\begin{array}{l}\text { Aktivitas fisik (eg. pendakian ringan), } \\
\text { berkemah, menikmati keindahan, berfoto } \\
\text { (eg. swafoto, fotografi) }\end{array}$ & $4,0(n=549)$ \\
\hline 5 & Gunung Masjid & Wisata alam & $\begin{array}{l}\text { Aktivitas fisik (eg. pendakian ringan), } \\
\text { menikmati keindahan, berfoto (eg. swafoto, } \\
\text { fotografi) }\end{array}$ & $4,3(n=31)$ \\
\hline 6 & Alun-alun Ponorogo & $\begin{array}{l}\text { Wisata } \\
\text { perkotaan }\end{array}$ & $\begin{array}{l}\text { Aktivitas sosial (eg. bercengkrama, kumpul } \\
\text { keluarga); aktivitas fisik (eg. olahraga); } \\
\text { kuliner; festival (eg. musik, kesenian } \\
\text { tradisional) }\end{array}$ & $4,4(n=324)$ \\
\hline 7 & $\begin{array}{l}\text { Taman Wisata } \\
\text { Ngembag }\end{array}$ & Wisata buatan & $\begin{array}{l}\text { Aktivitas fisik (eg. jalan santai, renang, } \\
\text { perahu kayuh / becak air), berfoto (eg. } \\
\text { Swafoto), perkumpulan sosial / komunitas, } \\
\text { festival seni }\end{array}$ & $3,8(\mathrm{n}=379)$ \\
\hline 8 & Beji Sirah Keteng & $\begin{array}{l}\text { Wisata } \\
\text { peninggalan } \\
\text { sejarah }\end{array}$ & $\begin{array}{l}\text { Edukasi; aktivitas fisik (eg. jalan santai), } \\
\text { menikmati keindahan, berfoto (eg. swafoto, } \\
\text { fotografi) }\end{array}$ & $4,2(n=116)$ \\
\hline 9 & $\begin{array}{l}\text { Sendang Beji } \\
\text { Tunggul Wulung }\end{array}$ & Wisata alam & $\begin{array}{l}\text { Aktivitas fisik (eg. jalan santai, perahu } \\
\text { kayuh / becak air, memancing), menikmati } \\
\text { keindahan, berfoto (eg. swafoto, fotografi), } \\
\text { festival seni }\end{array}$ & $4,1(n=44)$ \\
\hline 10 & Gunung Gajah & Wisata alam & $\begin{array}{l}\text { Aktivitas fisik (eg. pendakian ringan), } \\
\text { menikmati keindahan, berfoto (eg. swafoto, } \\
\text { fotografi) }\end{array}$ & $4,5(n=52)$ \\
\hline 11 & Kedung Gamping & Wisata alam & $\begin{array}{l}\text { Aktivitas fisik (eg. renang), menikmati } \\
\text { keindahan, berfoto (eg. swafoto, fotografi) }\end{array}$ & $4,2(n=25)$ \\
\hline 12 & Watu Putih & Wisata alam & $\begin{array}{l}\text { Aktivitas fisik (eg. pendakian ringan), } \\
\text { menikmati keindahan, berfoto (eg. swafoto, } \\
\text { fotografi) }\end{array}$ & $4,4(n=15)$ \\
\hline 13 & Watu Semaur & Wisata alam & $\begin{array}{l}\text { Aktivitas fisik (eg. pendakian ringan), } \\
\text { menikmati keindahan, berfoto (eg. swafoto, } \\
\text { fotografi) }\end{array}$ & $4,2(n=163)$ \\
\hline 14 & Air Terjun Selorejo & Wisata alam & $\begin{array}{l}\text { Aktivitas fisik (eg. pendakian ringan, } \\
\text { renang), menikmati keindahan, berfoto (eg. } \\
\text { swafoto, fotografi) }\end{array}$ & $4,4(n=20)$ \\
\hline 15 & Telaga Ngebel & Wisata alam & $\begin{array}{l}\text { Aktivitas fisik (eg. jalan santai, perahu } \\
\text { kayuh / becak air, memancing), menikmati } \\
\text { keindahan, berfoto (eg. swafoto, fotografi), } \\
\text { festival seni }\end{array}$ & $4,4(n=973)$ \\
\hline 16 & $\begin{array}{l}\text { Sumber Air Panas } \\
\text { Wagir Lor Ngebel }\end{array}$ & Wisata alam & $\begin{array}{l}\text { Mandi air hangat, berfoto (eg. swafoto), } \\
\text { menikmati keindahan }\end{array}$ & $4,0(n=166)$ \\
\hline 17 & $\begin{array}{l}\text { Air Terjun Coban } \\
\text { Lawe }\end{array}$ & Wisata alam & $\begin{array}{l}\text { Aktivitas fisik (eg. bermain air), menikmati } \\
\text { keindahan, berfoto (eg. swafoto, fotografi) }\end{array}$ & $4,4(n=108)$ \\
\hline 18 & Tanah Goyang & Wisata alam & $\begin{array}{l}\text { Aktivitas fisik (eg. pendakian ringan), } \\
\text { menikmati keindahan, berfoto (eg. swafoto, } \\
\text { fotografi) }\end{array}$ & $4,2(n=95)$ \\
\hline 19 & Air Terjun Pletuk & Wisata alam & $\begin{array}{l}\text { Aktivitas fisik (eg. pendakian ringan, } \\
\text { renang), menikmati keindahan, berfoto (eg. } \\
\text { swafoto, fotografi) }\end{array}$ & $3,9(n=127)$ \\
\hline 20 & Gunung Bedes & Wisata alam & $\begin{array}{l}\text { Aktivitas fisik (eg. pendakian ringan), } \\
\text { menikmati keindahan, berfoto (eg. swafoto, } \\
\text { fotografi) }\end{array}$ & $4,4(n=102)$ \\
\hline
\end{tabular}




\section{Komponen Aksesibilitas (Accessibility)}

Analisis ini meliputi akses jalan berupa jarak dan kondisi jalan dari pusat Ponorogo, serta ketersediaan transportasi umum. Dalam riset ini, jarak dari pusat kota mejadi aspek yang diikutsertakan dalam perhitungan karena seringkali menentukan keputusan dari wisatawan untuk berkunjung atau tidak ke obyek wisata tersebut. Kondisi jalan dianalisis dengan menghitung panjang jalan yang yang sudah diperkeras atau belum dengan berbagai jenis perkerasan seperti aspal, bebatuan, atau tanah. Terakhir, keberadaan transportasi umum juga diobservasi untuk menunjukkan keberadaan fasilitas transportasi yang dapat membantu wisatawan mengakses obyek wisata tertentu.

Secara umum bila dilihat dari komponen aksesibilitas, beberapa obyek wisata memiliki akses jalan raya yang sudah baik (aspal), akan tetapi ada beberapa kondisi jalan yang masih tanah bebatuan dengan jarak yang cukup panjang. Untuk ketersediaan transportasi umum, secara dominan memang obyek-obyek wisata tersebut sudah terjangkau transportasi umum berupa angkot dan ojek. Hanya 6 dari 20 obyek wisata yang belum terjangkau oleh transportasi umum baik angkot ataupun ojek. Berikutnya adalah tempat parkir, hanya terdapat 1 obyek wisata yang tidak memiliki tempat parkir baik yang disediakan resmi oleh pemerintaha, pengelola wisata, ataupun secara informal menggunakan lahan milik penduduk lokal. Rincian dari data-data komponen aksesibilitas untuk kedua puluh obyek wisata disajikan dalam Tabel 5 .

\begin{tabular}{|c|c|c|c|c|c|}
\hline No & Obyek Wisata & $\begin{array}{c}\text { Jarak } \\
\text { dari } \\
\text { Pusat }\end{array}$ & Kondisi jalan & $\begin{array}{c}\text { Transportasi } \\
\text { Umum }\end{array}$ & Tempat Parkir \\
\hline 1 & Kedung Khentus & 21.9 & $\begin{array}{l}\text { Aspal }(19.1 \mathrm{~km}), \text { tanah } \\
\text { bebatuan }(2.8 \mathrm{~km})\end{array}$ & Ada & Ada (mobil, motor) \\
\hline 2 & Hutan Wisata Kucur & 19.7 & Aspal sepenuhnya & Ada & Ada (mobil, motor) \\
\hline 3 & $\begin{array}{l}\text { Air Terjun Bukit } \\
\text { Seberang }\end{array}$ & 21.1 & $\begin{array}{l}\text { Aspal }(20.2 \mathrm{~km}) \text {, tanah } \\
\text { bebatuan }(0.9 \mathrm{~km})\end{array}$ & Tidak ada & Ada (mobil, motor) \\
\hline 4 & Gunung Beruk & 21.3 & $\begin{array}{l}\text { Aspal }(20.6 \mathrm{~km}), \text { tanah } \\
\text { bebatuan }(0.7 \mathrm{~km})\end{array}$ & Tidak ada & Ada (mobil, motor) \\
\hline 5 & Gunung Masjid & 21.8 & $\begin{array}{l}\text { Aspal }(21.4 \mathrm{~km}), \text { tanah } \\
\text { bebatuan }(0.4 \mathrm{~km})\end{array}$ & Tidak ada & Ada (motor) \\
\hline 6 & Alun-alun Ponorogo & o & Aspal sepenuhnya & Ada & Ada (mobil, motor) \\
\hline 7 & $\begin{array}{l}\text { Taman Wisata } \\
\text { Ngembag }\end{array}$ & 3.9 & Aspal sepenuhnya & Ada & Ada (mobil, motor) \\
\hline 8 & Beji Sirah Keteng & 15.1 & Aspal sepenuhnya & Ada & Ada (mobil, motor) \\
\hline 9 & $\begin{array}{l}\text { Sendang Beji Tulung } \\
\text { Wulung }\end{array}$ & 17.6 & Aspal sepenuhnya & Ada & Ada (mobil, motor) \\
\hline 10 & Gunung Gajah & 23.2 & $\begin{array}{l}\text { Aspal }(21.6 \mathrm{~km}), \text { tanah } \\
\text { bebatuan }(1.6 \mathrm{~km})\end{array}$ & Ada & Ada (mobil, motor) \\
\hline 11 & Kedung Gamping & 28.7 & Aspal sepenuhnya & Ada & Ada (mobil, motor) \\
\hline 12 & Watu Putih & 30.8 & Aspal sepenuhnya & Ada & Ada (motor) \\
\hline 13 & Watu Semaur & 34 & Aspal sepenuhnya & Ada & Tidak ada \\
\hline 14 & Air Terjun Selorejo & 33.1 & Aspal sepenuhnya & Tidak ada & Ada (motor) \\
\hline 15 & Telaga Ngebel & 23 & Aspal sepenuhnya & Ada & Ada (mobil, motor) \\
\hline 16 & $\begin{array}{l}\text { Sumber Air Panas } \\
\text { Wagir Lor Ngebel }\end{array}$ & 24.4 & Aspal sepenuhnya & Ada & Ada (mobil, motor) \\
\hline 17 & $\begin{array}{l}\text { Air Terjun Coban } \\
\text { Lawe }\end{array}$ & 33,33 & $\begin{array}{l}\text { Aspal }(29 \mathrm{~km}), \text { tanah } \\
\text { bebatuan }(4,33 \mathrm{~km})\end{array}$ & Tidak ada & Ada (motor) \\
\hline 18 & Tanah Goyang & 32.6 & Aspal sepenuhnya & Tidak ada & Ada (motor) \\
\hline 19 & Air Terjun Pletuk & 27.2 & Aspal sepenuhnya & Ada & Ada (motor) \\
\hline 20 & Gunung Bedes & 33.4 & $\begin{array}{l}\text { Aspal }(27.7 \mathrm{~km}) \text {, tanah } \\
\text { bebatuan }(5.7 \mathrm{~km})\end{array}$ & Ada & Ada (motor) \\
\hline
\end{tabular}

Sumber: Penulis, 2020

\section{Amenitas (Amenity)}

Amenitas menjadi salah satu komponen yang juga penting karena menentukan kualitas layanan fasilitas yang diterima oleh wisatawan selama berada di lokasi obyek wisata atua di sekitarnya. Penilaian pada komponen fasilitas meliputi akomodasi terdekat, tempat ibadah, warung makan / restoran, tempat parkir, dan toilet.

Dari sisi akomodasi, banyak obyek wisata di Ponorogo belum didukung dengan keberadaan akomodasi di dekatnya. Untuk tempat ibadah, beberapa obyek sudah memiliki mushola yang dibangun sederhana oleh pengelola obyek wisata. Warung makan atau restoran menjadi amenitas yang secara dominan melayani obyek wisata yang ada di Ponorogo, hanya ada 1 obyek wisata yang tidak terlayani warung makan / restoran. Tempat parkir sebagai salah satu amenitas juga belum melayani seluruh obyek wisata baik itu yang disediakan khusus ataupun yang dibuat secara organis oleh penduduk lokal. Amenitas terakhir adalah toilet yang juga belum terdapat 
pada seluruh obyek wisata karena beberapa obyek wisata dan penilaian secara lengkap dapat dilihat di tabel 6 . yang masih berkarakter sangat alamiah. Hasil observasi

Tabel 6. Data Komponen Amenitas

\begin{tabular}{clllll}
\hline No & \multicolumn{1}{c}{ Obyek Wisata } & $\begin{array}{c}\text { Akomodasi } \\
\text { terdekat }\end{array}$ & $\begin{array}{c}\text { Tempat } \\
\text { Ibadah }\end{array}$ & $\begin{array}{c}\text { Warung Maka: } \\
\text { / Restoran }\end{array}$ & Toilet \\
\hline $\mathbf{1}$ & Kedung Khentus & Tidak ada & Tidak ada & Ada & Tidak ada \\
$\mathbf{2}$ & Hutan Wisata Kucur & Tidak ada & Ada & Ada & Ada \\
3 & Air Terjun Bukit Seberang & Tidak ada & Tidak ada & Ada & Ada \\
4 & Gunung Beruk & Tidak ada & Tidak ada & Ada & Tidak ada \\
5 & Gunung Masjid & Tidak ada & Tidak ada & Ada & Tidak ada \\
6 & Alun-alun Ponorogo & Ada & Ada & Ada & Ada \\
7 & Taman Wisata Ngembag & Ada & Ada & Ada & Ada \\
8 & Beji Sirah Keteng & Tidak ada & Ada & Ada & Ada \\
9 & Sendang Beji Tulung Wulung & Ada & Ada & Ada & Ada \\
10 & Gunung Gajah & Tidak ada & Tidak ada & Ada & Tidak ada \\
$\mathbf{1 1}$ & Kedung Gamping & Tidak ada & Ada & Ada & Ada \\
12 & Watu Putih & Ada & Tidak ada & Ada & Ada \\
13 & Watu Semaur & Ada & Tidak ada & Ada & Ada \\
14 & Air Terjun Selorejo & Tidak ada & Tidak ada & Tidak ada & Tidak ada \\
15 & Telaga Ngebel & Tidak ada & Ada & Ada & Ada \\
16 & Sumber Air Panas Wagir Lor Ngebel & Tidak ada & Ada & Ada & Ada \\
$\mathbf{1 7}$ & Air Terjun Coban Lawe & Tidak ada & Ada & Ada & Ada \\
$\mathbf{1 8}$ & Tanah Goyang & Tidak ada & Ada & Ada & Ada \\
$\mathbf{1 9}$ & Air Terjun Pletuk & Ada & Ada & Ada & Ada \\
\hline $\mathbf{2 0}$ & Gunung Bedes & Tidak ada & Tidak ada & Ada & Tidak ada \\
\hline
\end{tabular}


Tabel 7. Data Komponen Penyokong

\begin{tabular}{|c|c|c|c|c|}
\hline No & Obyek Wisata & Informasi / ulasan & $\begin{array}{l}\text { Penunjuk / } \\
\text { penanda }\end{array}$ & Peta \\
\hline 1 & Kedung Khentus & Ada (blog, forum) & Tidak ada & Ada (Google map) \\
\hline 2 & Hutan Wisata Kucur & Ada (blog, forum) & Tidak ada & Ada (Google map) \\
\hline 3 & Air Terjun Bukit Seberang & Ada (blog, forum) & Tidak ada & Ada (Google map) \\
\hline 4 & Gunung Beruk & Ada (website resmi, blog, forum) & Ada & Ada (Google map) \\
\hline 5 & Gunung Masjid & Ada (blog, forum) & Tidak ada & Ada (Google map) \\
\hline 6 & Alun-alun Ponorogo & Ada (blog, forum) & Ada & Ada (Google map) \\
\hline 7 & Taman Wisata Ngembag & Ada (blog, forum) & Tidak ada & Ada (Google map) \\
\hline 8 & Beji Sirah Keteng & Ada (blog, forum) & Tidak ada & Ada (Google map) \\
\hline 9 & $\begin{array}{l}\text { Sendang Beji Tulung } \\
\text { Wulung }\end{array}$ & Ada (blog, forum) & Tidak ada & Ada (Google map) \\
\hline 10 & Gunung Gajah & Ada (website resmi, blog, forum) & Tidak ada & Ada (Google map) \\
\hline 11 & Kedung Gamping & Ada (blog, forum) & Tidak ada & Ada (Google map) \\
\hline 12 & Watu Putih & Ada (blog, forum) & Tidak ada & Ada (Google map) \\
\hline 13 & Watu Semaur & Ada (blog, forum) & Tidak ada & Ada (Google map) \\
\hline 14 & Air Terjun Selorejo & Ada (blog, forum) & Ada & Ada (Google map) \\
\hline 15 & Telaga Ngebel & Ada (website resmi, blog, forum) & Ada & Ada (Google map) \\
\hline 16 & $\begin{array}{l}\text { Sumber Air Panas Wagir } \\
\text { Lor Ngebel }\end{array}$ & Ada (website resmi, blog, forum) & Ada & Ada (Google map) \\
\hline 17 & Air Terjun Coban Lawe & Ada (website resmi, blog, forum) & Tidak ada & Ada (Google map) \\
\hline 18 & Tanah Goyang & Ada (website resmi, blog, forum) & Tidak ada & Ada (Google map) \\
\hline 19 & Air Terjun Pletuk & Ada (website resmi, blog, forum) & Ada & Ada (Google map) \\
\hline 20 & Gunung Bedes & Ada (website resmi, blog, forum) & Ada & Ada (Google map) \\
\hline
\end{tabular}

Sumber: Penulis, 2020 
Tabel 8. Nilai Daya Tarik Per Atribut

\begin{tabular}{|c|c|c|c|c|c|c|c|c|c|c|c|c|c|c|c|c|}
\hline \multirow[b]{2}{*}{ No. } & \multirow[b]{2}{*}{ Obyek Wisata } & \multirow{2}{*}{$\begin{array}{c}\text { Atraksi } \\
\text { (1) }\end{array}$} & \multicolumn{4}{|c|}{ Aksesibilitas } & \multicolumn{4}{|c|}{ Amenitas } & \multicolumn{3}{|c|}{ Penyokong } & \multirow[b]{2}{*}{ Total } & \multirow[b]{2}{*}{ Peringkat } & \multirow[b]{2}{*}{ Daya Tarik } \\
\hline & & & (2) & (3) & (4) & (5) & (6) & (7) & (8) & (9) & (10) & (11) & (12) & & & \\
\hline 6 & Alun-alun Ponorogo & 1 & 1 & 1 & 1 & 1 & 1 & 1 & 1 & 1 & 1 & 1 & 1 & 12 & 1 & Sangat tinggi \\
\hline 9 & Sendang Beji Tulung Wulung & 1 & 1 & 1 & 1 & 1 & 1 & 1 & 1 & 1 & 1 & o & 1 & 11 & 2 & Tinggi \\
\hline 15 & Telaga Ngebel & 1 & 1 & 1 & 1 & 1 & 0 & 1 & 1 & 1 & 1 & 1 & 1 & 11 & 2 & Tinggi \\
\hline 16 & $\begin{array}{l}\text { Sumber Air Panas Wagir Lor } \\
\text { Ngebel }\end{array}$ & 1 & 1 & 1 & 1 & 1 & $\mathrm{O}$ & 1 & 1 & 1 & 1 & 1 & 1 & 11 & 2 & Tinggi \\
\hline 2 & Hutan Wisata Kucur & 1 & 1 & 1 & 1 & 1 & o & 1 & 1 & 1 & 1 & o & 1 & 10 & 3 & Agak Tinggi \\
\hline 7 & Taman Wisata Ngembag & o & 1 & 1 & 1 & 1 & 1 & 1 & 1 & 1 & 1 & $\mathrm{o}$ & 1 & 10 & 3 & Agak Tinggi \\
\hline 8 & Beji Sirah Keteng & 1 & 1 & 1 & 1 & 1 & o & 1 & 1 & 1 & 1 & 0 & 1 & 10 & 3 & Agak Tinggi \\
\hline 19 & Air Terjun Pletuk & o & o & 1 & 1 & 1 & 1 & 1 & 1 & 1 & 1 & 1 & 1 & 10 & 3 & Agak Tinggi \\
\hline 11 & Kedung Gamping & 1 & o & 1 & 1 & 1 & o & 1 & 1 & 1 & 1 & 0 & 1 & 9 & 4 & Sedang \\
\hline 13 & Watu Semaur & 1 & o & 1 & 1 & 1 & 1 & o & 1 & 1 & 1 & o & 1 & 9 & 4 & Sedang \\
\hline 12 & Watu Putih & 1 & o & 1 & 1 & o & 1 & 0 & 1 & 1 & 1 & 0 & 1 & 8 & 5 & Agak Rendah \\
\hline 17 & Air Terjun Coban Lawe & 1 & o & 1 & o & 1 & o & 1 & 1 & 1 & 1 & 0 & 1 & 8 & 5 & Agak Rendah \\
\hline 18 & Tanah Goyang & 1 & o & 1 & o & 1 & o & 1 & 1 & 1 & 1 & o & 1 & 8 & 5 & Agak Rendah \\
\hline 20 & Gunung Bedes & 1 & o & 1 & 1 & 1 & o & o & 1 & o & 1 & $\begin{array}{lllll}1 & & & & \end{array}$ & 1 & 8 & 5 & Agak Rendah \\
\hline 1 & Kedung Khentus & 1 & 0 & 1 & 1 & 1 & 0 & 0 & 1 & 0 & 1 & 0 & 1 & 7 & 6 & Rendah \\
\hline 4 & Gunung Beruk & 1 & o & 1 & $\mathrm{O}$ & 1 & 0 & 0 & 1 & 0 & 1 & 1 & 1 & 7 & 6 & Rendah \\
\hline 10 & Gunung Gajah & 1 & o & 1 & 1 & 1 & o & o & 1 & o & 1 & o & 1 & 7 & 6 & Rendah \\
\hline 3 & Air Terjun Bukit Seberang & o & o & 1 & o & 1 & o & o & 1 & 1 & 1 & o & 1 & 6 & 7 & Sangat Rendah \\
\hline 5 & Gunung Masjid & 1 & 0 & 1 & 0 & 1 & 0 & 0 & 1 & 0 & 1 & 0 & 1 & 6 & 7 & Sangat Rendah \\
\hline 14 & Air Terjun Selorejo & 1 & o & 1 & o & 1 & o & o & 0 & 0 & 1 & 1 & 1 & 6 & 7 & Sangat Rendah \\
\hline & Total & 17 & 7 & 20 & 14 & 19 & 6 & 11 & 19 & 14 & 20 & 7 & 20 & & & \\
\hline
\end{tabular}

Keterangan atribut: (1) Rating atraksi; (2) Jarak dari pusat kota; (3) Kondisi jalan; (4) Transportasi umum; (5) Tempat parkir; (6) Akomodasi terdekat; (7) Tempat ibadah; (8) Warung makan / restoran; (9) Toilet; (10) Informasi / ulasan; (11) Penunjuk / penanda; (12) Peta 
Tabel 9. Nilai Daya Tarik Per Komponen

\begin{tabular}{|c|c|c|c|c|c|c|c|c|c|c|c|}
\hline & \multirow[b]{3}{*}{ Nilai Maks } & \multicolumn{8}{|c|}{ Nilai Per Komponen } & \multicolumn{2}{|c|}{ Nilai Total } \\
\hline & & Atraksi & $\%$ & Aksesibilitas & $\%$ & Amenitas & $\%$ & Penyokong & $\%$ & Angka & $\%$ \\
\hline & & \multicolumn{2}{|l|}{1} & \multicolumn{2}{|l|}{4} & \multicolumn{2}{|l|}{4} & \multicolumn{2}{|l|}{3} & \multicolumn{2}{|l|}{12} \\
\hline 1 & Kedung Khentus & 1 & $100 \%$ & 3 & $75 \%$ & 1 & $25 \%$ & 2 & $67 \%$ & 7 & $58 \%$ \\
\hline 2 & Hutan Wisata Kucur & 1 & $100 \%$ & 4 & $100 \%$ & 3 & $75 \%$ & 2 & $67 \%$ & 10 & $83 \%$ \\
\hline 3 & Air Terjun Bukit Seberang & o & $0 \%$ & 2 & $50 \%$ & 2 & $50 \%$ & 2 & $67 \%$ & 6 & $50 \%$ \\
\hline 4 & Gunung Beruk & 1 & $100 \%$ & 2 & $50 \%$ & 1 & $25 \%$ & 3 & $100 \%$ & 7 & $58 \%$ \\
\hline 5 & Gunung Masjid & 1 & $100 \%$ & 2 & $50 \%$ & 1 & $25 \%$ & 2 & $67 \%$ & 6 & $50 \%$ \\
\hline 6 & Alun-alun Ponorogo & 1 & $100 \%$ & 4 & $100 \%$ & 4 & $100 \%$ & 3 & $100 \%$ & 12 & $100 \%$ \\
\hline 7 & Taman Wisata Ngembag & o & o\% & 4 & $100 \%$ & 4 & $100 \%$ & 2 & $67 \%$ & 10 & $83 \%$ \\
\hline 8 & Beji Sirah Keteng & 1 & $100 \%$ & 4 & $100 \%$ & 3 & $75 \%$ & 2 & $67 \%$ & 10 & $83 \%$ \\
\hline 9 & Sendang Beji Tunggul Wulung & 1 & $100 \%$ & 4 & $100 \%$ & 4 & $100 \%$ & 2 & $67 \%$ & 11 & $92 \%$ \\
\hline 10 & Gunung Gajah & 1 & $100 \%$ & 3 & $75 \%$ & 1 & $25 \%$ & 2 & $67 \%$ & 7 & $58 \%$ \\
\hline 11 & Kedung Gamping & 1 & $100 \%$ & 3 & $75 \%$ & 3 & $75 \%$ & 2 & $67 \%$ & 9 & $75 \%$ \\
\hline 12 & Watu Putih & 1 & $100 \%$ & 2 & $50 \%$ & 3 & $75 \%$ & 2 & $67 \%$ & 8 & $67 \%$ \\
\hline 13 & Watu Semaur & 1 & $100 \%$ & 3 & $75 \%$ & 3 & $75 \%$ & 2 & $67 \%$ & 9 & $75 \%$ \\
\hline 14 & Air Terjun Selorejo & 1 & $100 \%$ & 2 & $50 \%$ & o & $0 \%$ & 3 & $100 \%$ & 6 & $50 \%$ \\
\hline 15 & Telaga Ngebel & 1 & $100 \%$ & 4 & $100 \%$ & 3 & $75 \%$ & 3 & $100 \%$ & 11 & $92 \%$ \\
\hline 16 & Sumber Air Panas Wagir Lor Ngebel & 1 & $100 \%$ & 4 & $100 \%$ & 3 & $75 \%$ & 3 & $100 \%$ & 11 & $92 \%$ \\
\hline 17 & Air Terjun Coban Lawe & 1 & $100 \%$ & 2 & $50 \%$ & 3 & $75 \%$ & 2 & $67 \%$ & 8 & $67 \%$ \\
\hline 18 & Tanah Goyang & 1 & $100 \%$ & 2 & $50 \%$ & 3 & $75 \%$ & 2 & $67 \%$ & 8 & $67 \%$ \\
\hline 19 & Air Terjun Pletuk & o & o\% & 3 & $75 \%$ & 4 & $100 \%$ & 3 & $100 \%$ & 10 & $83 \%$ \\
\hline \multirow[t]{2}{*}{20} & Gunung Bedes & 1 & $100 \%$ & 3 & $75 \%$ & 1 & $25 \%$ & 3 & $100 \%$ & 8 & $67 \%$ \\
\hline & Mean & 0,85 & $85 \%$ & 3,00 & $75 \%$ & 2,50 & $62,5 \%$ & 2,35 & $78,33 \%$ & 9 & $72,5 \%$ \\
\hline
\end{tabular}




\section{Komponen Penyokong (Ancilliary)}

Selain 3 komponen di atas, komponen penyokong juga tidak dapat lepas sebagai komponen pembentuk daya tarik obyek wisata. Pada riset ini komponen penyokong meliputi atribut informasi / ulasan terkait obyek wisata, keberadaan penunjuk atah / penanda, serta akses terhadap peta-peta baik fisik maupun digital. Pada atribut informasi / ulasan, seluruh obyek wisata dapat dengan mudah ditemui informasi / ulasannya terutama pada blog dan forum daring bertopik wisata. Era teknologi informasi benar-benar memberikan kemudahan dalam mengakses informasi pariwisata. Pada atribut penunjuk arah / penanda, memang belum seluruh obyek wisata diberikan fasilitas tersebut. Terhitung 7 dari 20 obyek wisata belum memiliki penunjuk arah / penanda. Untuk atribut ketiga yaitu peta, hasil pencarian dengan Google Maps menunjukkan bahwa seluruh obyek wisata telah terdata dalam database Google Maps dan valid secara geografis, sehingga sangat membantu pencarian lokasi obyek wisata.

\section{Temuan dan Diskusi Penilaian Daya Tarik Wisata}

Berdasarkan pada data-data yang telah dipaparkan pada bagian sebelumnya, sistem penilaian biner lalu diaplikasikan pada kedua belas atribut untuk mensintesis nilai daya tarik obyek-obyek wisata yang menjadi kasus penelitian. Teknik penilaian mengacu pada kerangka yang telah dijelaskan pada Tabel 2 bab metode. Hasil penilaian biner untuk 12 atribut dalam keempat komponen pendukung daya tarik obyek wisata disajikan dalam Tabel 8. Urutan obyek wisata yang disajikan dalam tabel tersebut disusun berdasarkan nilai tertinggi ke nilai terendah. Bila dilihat dari hasil penilaian total, terdapat 7 kategori peringkat dan daya tarik, dengan 12 sebagai nilai tertinggi dan 6 yang terendah. Kategori peringkat tersebut dipadankan dengan kategori daya tarik secara relatif agar memudahkan intepretasi nilai. Padanan peringkat dan daya tarik tersebut adalah: peringkat $1=$ sangat tinggi, peringkat $2=$ tinggi, peringkat $3=$ agak tinggi, peringkat $4=$ sedang, peringkat $5=$ agak rendah, peringkat $6=$ rendah, dan peringkat $7=$ sangat rendah.

Penjelasan rinci dari peringkat dan kategori daya tarik dijelaskan sebagai berikut. Kategori peringkat 1 (sangat tinggi) adalah obyek wisata yang mendapatkan nilai sempurna sebesar 12, hanya ada 1 obyek wisata yaitu Alun-Alun Ponorogo. Kategori peringkat 2 (tinggi) adalah obyek wisata dengan nilai 11 sebanyak 3 obyek. Kategori peringkat 3 (agak tinggi) dengan nilai 10 sebanyak 4 obyek wisata. Kategori peringkat 4 (sedang) dengan nilai sebesar 9 sebanyak 2 obyek wisata. Kategori peringkat 5 (agak rendah) dengan nilai total 8 sebanyak 4 obyek wisata. Kategori nilai 6 (rendah) dengan nilai total 7 sebanyak 3 obyek wisata. Terakhir adalah kategori nilai 7 (sangat rendah) dengan nilai total 6 sebanyak 3 obyek wisata. Peringkat berdasarkan nilai tersebut menunjukkan gambaran relatif tingkat daya tarik dari masing-masing obyek wisata. Informasi ini sangat bermanfaat untuk penentuan prioritas pengembangan obyek wisata sebuah di masa depan, dengan begitu target pengembangan obyek wisata akan jauh lebih tepat dan efektif.

Selanjutnya, adalah temuan hasil penilaian berdasarkan atribut daya tarik. Jika dilihat dari nilai atribut 'atraksi', terdapat 3 obyek wisata mendapat nilai o antara lain Taman Wisata Ngembag, Air Terjun Pletuk, dan Air Terjun Bukit Seberang. Untuk atribut 'jarak dari pusat kota', 13 obyek wisata mendapatkan nilai o karena lokasinya yang memang cukup jauh dari pusat kota. Meskipun jarak merupakan atribut yang tidak bisa diintervensi, dengan mengatahui lokasi obyek wisata, perencana wisata dapat merumuskan rencana untuk mensiasati jarak yang jauh. Untuk atribut 'kondisi jalan', kedua puluh obyek wisata mendapatkan nilai 1 . Pada atribut 'transportasi umum', terdapat 6 obyek wisata yang mendapatkan nilai $\mathrm{o}$ atau tidak terjangkau transportasi umum sama sekali. Untuk atribut 'tempat parkir', hanya terdapat 1 obyek wisata yang mendapatkan nilai o yaitu Watu Putih karena tidak memiliki lahan parkir sama sekali.

Untuk atribut-atribut di bawah komponen amenitas, hasil penilaiannya adalah sebagai berikut. Untuk atribut 'akomodasi terdekat' hanya terdapat 6 obyek yang mendapatkan nilai 1, artinya baru sebagian kecil saja obyek wisata yang sudah terlayani akomodasi dengan jarak yang relatif dekat. Untuk atribut 'tempat ibadah' sebanyak 9 obyek mendapatkan nilai o. Untuk atribut 'warung makan / restoran' hanya 1 obyek yang mendapatkan nilai o, dengan kata lain sebagian besar obyek wisata telah didukung amenitas warung atau restoran. Atribut terakhir untuk komponen amenitas adalah toilet, sebanyak 6 obyek wisata mendapatkan nilai o atau belum memiliki fasilitas toilet.

Penjelasan berikutnya adalah penilaian untuk atribut di bawah komponen penyokong. Atribut pertama adalah 'keberadaan informasi / ulasan' obyek wisata, seluruh obyek wisata mendapat nilai 1 atau telah memiliki informasi yang mudah diakses oleh turis terutama akses informasi daring. Untuk atribut 'penunjuk atau penanda' hanya 6 obyek wisata yang mendapat 1, artinya sebagian besar obyek wisata belum diberikan fasilitas tersebut. Atribut terakhir adalah 'peta', seluruh obyek wisata mendapatkan nilai 1 yang artinya telah memiliki peta yang dapat diakses oleh turis terutama peta daring.

Riset ini juga mencoba melihat pola-pola yang muncul dari hasil penilaian daya tarik wisata berdasarkan komponen 4A, yang hasilnya disajikan dalam tabel 9 . Secara umum, tiga komponen Atraksi, Aksesibilitas, dan Penyokong secara rata-rata mendapatkan nilai yang cukup baik yaitu $85 \%, 75 \%$, dan $78 \%$ secara berurutan. 
Angka rata-rata daya tarik per komponen tersebut lebih tinggi dibandingkan angka rata-rata persentase total sebesar $72,5 \%$. Sedangkan daya tarik terendah terdapat di komponen Amenitas dengan rata-rata nilai 2,5 dan rata-rata persentase $62,5 \%$. Ini mengindikasikan bahwa tingkat daya tarik obyek-obyek wisata yang ada di Ponorogo belum sempurna, baik secara total maupun per komponen pembentuknya.

\section{Manfaat Penilaian Daya Tarik Obyek Wisata}

Setidaknya terdapat 2 manfaat yang didapatkan dari penilaian daya tarik obyek wisata: (1). Mengidentifikasi nilai dan peringkat daya tarik masingmasing obyek wisata sehingga dapat ditentukan secara tepat sasaran obyek wisata mana yang diprioritaskan akan dikembangkan; (2). Memahami kondisi dan kinerja dari masing-masing komponen dan atribut pada setiap obyek wisata sehingga dapat ditentukan program dan kegiatan yang tepat guna dalam rangka mengembangkan obyek wisata.

Berikut adalah ilustrasi dari manfaat-manfaat tersebut. Pertama, hasil penilaian daya tarik obyek wisata mampu membantu pemilihan secara tepat sasaran obyek wisata yang diprioritaskan akan dikembangkan. Teridentifikasi bahwa terdapat 4 obyek wisata masuk dalam kategori daya tarik 'agak rendah', 3 obyek wisata masuk dalam kategori daya tarik 'rendah', dan 3 obyek wisata masuk dalam kategori daya tarik 'sangat rendah'. Dari hasil ini, seorang perencana wisata dapat menentukan apakah obyek-obyek wisata tersebut akan diprioritaskan dalam pengembangan ke depan atau justru prioritas pengembangan diarahkan pada obyek wisata yang sudah memiliki modal 'cukup' - yaitu obyek-obyek yang mendapatkan kategori daya tarik sedang hingga sangat tinggi.

Kedua, melalui hasil penilaian obyek wisata, seorang perencana pariwisata juga mengidentifikasi bentuk pembangunan (program dan kegiatan) apa yang harus dilakukan untuk mengembangkan obyek wisata yang kurang memiliki daya tarik. Manfaat semacam ini juga ditemui dalam penelitian-penelitian terdahulu $[6,12]$. Ilustrasi berikut menggunakan obyek wisata Air Terjun Selorejo sebagai contoh (nomor urut terakhir dalam Tabel 8). Dari hasil penilaian diketahui bahwa obyek wisata ini hanya mendapatkan nilai 6 atribut dari total 12 atribut yang ada dengan kategori daya tarik 'sangat rendah'. Ke 6 atribut tersebut antara lain jarak dari pusat kota, keberadaan transportasi umum, akomodasi terdekat, warung / restoran, tempat ibadah, toilet. Maka dalam perencanaan pengembangan wisata Air Terjun Selorejo, seorang perencana pariwisata dapat memprioritaskan pengembangan obyek tersebut pada beberapa program antara lain: (1) mengembangkan aksesibilitas Air Terjun Selorejo melalui paket transportasi wisata dan/atau pengembangan transportasi publik, dalam rangka mensiasati jarak obyek wisata yang jauh dari pusat kota sekaligus menyelesaikan masalah ketiadaan transportasi umum; (2) pengembangan amenitas berbasis komunitas lokal yang ada di sekitar Air Terjun Selorejo agar akomodasi, warung / restoran, tempat ibadah, hingga toilet dapat tersedia.

Kedua manfaat tersebut banyak pula ditemukan dalam riset penilaian daya tarik obyek wisata sebelumnya. Melalui penilaian daya tarik wisata, para peneliti berhasil mengidentifikasi obyek wisata mana yang perlu dibantu perkembangannya serta kelemahan dari tiap atribut pendukung daya tarik wisata obyek tersebut [14,16]. Dari hasil identifikasi kelemahan tersebut maka bisa dirumuskan arahan-arahan pengembangan obyek wisata dari aspek seperti: peningkatan kualitas dan jumlah aktivitas yang ditawarkan sebuah obyek wisata, peningkatan kualitas infrastruktur baik eksternal (aksesibilitas) maupun internal (amenitas), perbaikan manajemen dan tata kelola, hingga peningkatan mutu SDM $[4,6,12,23]$. Dari hasil tersebut target pengembangan obyek wisata akan lebih tepat sasaran.

\section{Implikasi Praktek dan Kebijakan Pengembangan Pariwisata}

Riset ini juga coba merumuskan implikasi pada praktek dan kebijakan pengembangan pariwisata di tingkat nasional dan lokal atau daerah serta rekomendasi kontekstual bagi Kabupaten Ponorogo:

1. Penilaian daya tarik dapat dilakukan sebagai langkah penilaian awal (preliminary assessment) dari kondisi dan kinerja aktual dari obyek-obyek wisata yang ada, baik terbatas pada tingkat lokal ataupun nasional. Penilaian daya tarik dapat menjadi pendekat (proxy) untuk mengidentifikasi tingkat keunggulan dari obyek wisata. Di tengah kompetisi yang sengit di sektor industri wisata, memahami keunggulan (dan kekurangan) yang dimiliki merupakan langkah awal yang tepat sebelum merumuskan strategi-strategi pengembangan pariwisata baik di tingkat lokal maupun nasional. Dengan begitu, alokasi sumberdaya yang digunakan dapat tetap sasaran dan tepat guna.

2. Secara kontekstual bagi Kabupaten Ponorogo, penilaian daya tarik ini menunjukkan bahwa ada beberapa obyek wisata di Ponorogo yang membutuhkan perhatian lebih untuk dikembangkan. Kelemahankelemahan dari obyek wisata tersebut bersifat unik meskipun terdapat pola-pola kesamaan yang muncul. Sehingga dalam perencanaanya perlu dilakukan penilaian yang spesifik pada setiap obyek wisata. Meskipun riset ini tidak menggunakan semua destinasi wisata yang ada di Ponorogo, setidaknya gambaran tentang tingkat daya tarik obyek-obyek yang ada sudah berhasil ditangkap dalam riset ini. Selanjutnya, Kabupaten Ponorogo dapat melakukan kajian serupa yang mengikutsertakan seluruh obyek wisata yang dimiliki agar perumusan kebijakan pembangunan 
pariwisata efisien dari sisi sumberdaya dan efektif dari aspek program dan kegiatan.

\section{Keterbatasan dan Potensi Riset Berikutnya}

Peneliti mengakui beberapa keterbatasan dari riset ini. Pertama, adalah keterbatasan atribut yang digunakan. Dalam riset ini, penilaian daya tarik obyek wisata menggunakan 12 atribut yang mewakili sudut pandang supply atau sumberdaya yang dimiliki oleh obyek wisata. Jumlah ini dirasa masih sangat terbatas dan dapat dikembangkan dalam riset-riset selanjutnya. Dalam literatur ada ragam komponen dan atribut yang dapat digunakan dan diuji dalam menilai daya tarik baik dari sudut pandang supply yaitu sumberdaya yang dimiliki obyek wisata $[14,17]$ maupun demand atau persepsi turis terhadap daya tarik $[12,13,16]$ serta kaitan keduanya $[8,13,20,37]$. Dengan memperkaya jumlah atribut yang digunakan, keunggulan dan kelemahan obyek wisata yang menentukan tingkat daya tarik obyek tersebut dapat diketahui lebih rinci.

Kedua, riset ini menggunakan sistem penilaian yang sederhana yaitu biner. Bentuk-bentuk penilaian lainya tidak menutup kemungkinan untuk digunakan dan diuji dalam riset-riset di masa depan. Sebagai contoh misalnya [14] yang menggunakan metode $A H P$ dalam membobotkan atribut dan komponen penentu tingkat daya tarik wisata. Contoh lainnya adalah [15] yang menggunakan metode unik seperti SMAA (stochastic multicriteria acceptability analysis) dalam menilai daya tarik obyek wisata.

\section{E. KESIMPULAN}

Riset ini menunjukkan bahwa penilaian daya tarik dengan metode penilaian sederhana yaitu biner, mampu mengungkap daya tarik per obyek wisata yang terbagi lagi secara rinci ke dalam tiap atribut pembentuk daya tarik. Selain itu, peringkat dan kategori daya tarik obyek wisata berhasil diidentifikasi secara obyektif. Dari nilai yang didapatkan, kedua puluh obyek tersebut kemudian dikategorisasi ke dalam 7 kategori tingkat daya tarik. Kategorisasi ini merupakan gambaran tingkat daya tarik relative yang dimiliki tiap obyek tersebut. Hasil menunjukkan bahwa terdapat 1 obyek wisata yang masuk kategori sangat tinggi. Kategori tinggi sebanyak 3 obyek, kategori agak tinggi sebanyak 4 obyek wisata. Kategori sedang sebanyak 2 obyek wisata. Selanjutnya kategori agak rendah sebanyak 4 obyek wisata, kategori rendah sebanyak 3 obyek wisata. Terakhir adalah kategori sangat rendah sebanyak 3 obyek wisata. Hasil dari kategorisasi ini sangat bermanfaat untuk merumuskan prioritas pengembangan obyek wisata di masa depan.

Selanjutnya, riset ini juga mengungkap pola nilai berdasarkan komponen pembentuk daya tarik wisata. Terungkap bahwa nilai rata-rata total dari daya tarik wisata yang ada di area penelitian memiliki nilai total 72,5 dari 100. Informasi lebih rinci didapatkan bila menyorot nilai rata-rata dalam 4 komponen berbeda yaitu atraksi, aksesibilitas, amenitas, dan penyokong. Keempat komponen tersebut mendapatkan nilai daya tarik rata-rata sebesar 85, 75, 62,5, dan 78,33 dari 100. Amenitas menempati peringkat terendah atau mengindikasikan dukungan fasilitas yang kurang dalam membentuk daya tarik sebuah obyek wisata.

Riset ini juga telah menunjukkan bahwa dengan menilai daya tarik obyek wisata dengan mengikutsertakan beragam komponen dan atribut dapat membantu mengidentifikasi kelemahan dan kekurangan dari sebuah obyek wisata secara rinci. Teridentifikasinya kelemahan dan kekurangan tiap atribut tersebut dapat membantu pengalokasian sumberdaya pembangunan lebih tepat sasaran dan tepat guna kepada atributatribut pendukung daya tarik yang masih lemah dan kurang. Dari hasil tersebut target pengembangan obyek wisata akan jauh lebih tepat dan efektif.

\section{PERNYATAAN RESMI}

RBA merancang dan menulis tinjauan pustaka, metode, mengembangkan hasil analisis dan diskusi. CA mengumpulkan data, melakukan dan menulis hasil analisis awal. Seluruh penulis telah sepakat dengan isi dari artikel ini. Seluruh penulis mendeklarasikan tidak ada konflik kepentingan terkait artikel ini.

\section{DAFTAR RUJUKAN}

1. Crouch GI. Destination competitiveness: An analysis of determinant attributes. J Travel Res. 50(1):27452011;

2. Kastenholz E, Eusébio C, Figueiredo E, Lima J. Accessibility as competitive advantage of a tourism destination: The case of Lousã. Adv Cult Tour Hosp Res. 6:369-852012;

3. Abreu-Novais M, Ruhanen L, Arcodia C. Destination competitiveness: what we know, what we know but shouldn't and what we don't know but should. Vol. 19, Current Issues in Tourism. Routledge; p. 4925122016.

4. Dwyer L, Dragićević V, Armenski T, Mihalič T, Knežević Cvelbar L. Achieving destination competitiveness: an importance-performance analysis of Serbia. Curr Issues Tour. 19(13):1309-362016 Nov 9;

5. Dwyer L, Kim C. Destination competitiveness: Determinants and indicators. Curr Issues Tour. 6(5):369-4142003;

6. Ma E, Hsiao A, Gao J (Jessica). Destination attractiveness and travel intention: the case of Chinese and Indian students in Queensland, Australia. Asia Pacific J Tour Res. 23(2):200-152018;

7. Reisinger Y, Michael N, Hayes JP. Destination competitiveness from a tourist perspective: A case of the United Arab Emirates. Int J Tour Res. 21(2):259792019; 
8. Formica S, Uysal M. Destination attractiveness based on supply and demand evaluations: An analytical framework. J Travel Res. 44(4):418-302006;

9. Chen CY, Sok P, Sok K. Evaluating the competitiveness of the tourism industry in Cambodia: Self-assessment from professionals. Asia Pacific J Tour Res. 13(1):41-662008 Mar;

10. Yangzhou H, Ritchie JRB. Measuring Destination Attractiveness: A Contextual Approach. J Travel Res. 32(2):25-341993;

11. Reitsamer BF, Brunner-Sperdin A. Tourist destination perception and well-being: What makes a destination attractive? J Vacat Mark. 23(1):55-722015;

12. Ariya G, Wishitemi B, Sitati N. Tourism Destination Attractiveness as Perceived by Tourists Visiting Lake Nakuru National Park, Kenya. Int J Res Tour Hosp. 3(4):1-132017;

13. Chang S, Stansbie P. Commitment theory: do behaviors enhance the perceived attractiveness of tourism destinations? Tour Rev. 73(4):448-642018;

14. Lee CF. An investigation of factors determining industrial tourism attractiveness. Tour Hosp Res. 16(2):184-972016;

15. An LT, Markowski J, Bartos M, Rzenca A, Namiecinski P. An evaluation of destination attractiveness for nature-based tourism: Recommendations for the management of national parks in Vietnam. Nat Conserv. 32:51-802019;

16. Lee CF, Ou WM, Huang HI. A study of destination attractiveness through domestic visitors' perspectives: The case of Taiwan's hot springs tourism sector. Asia Pacific J Tour Res. 14(1):17-382009;

17. Azzopardi E, Nash R. A framework for island destination competitiveness - perspectives from the island of Malta. Curr Issues Tour. 19(3):253-812016 Feb 23;

18. Lee CF, Huang HI, Yeh HR. Developing an evaluation model for destination attractiveness: Sustainable forest recreation tourism in Taiwan. $\mathbf{J}$ Sustain Tour. 18(6):811-282010;

19. Kokt D, Hattingh J. Local economic development, rural tourism and communities. In: The Routledge Handbook of Tourism Impacts. 2019.

20. Andrades-Caldito L, Sánchez-Rivero M, PulidoFernández JI. Tourism destination competitiveness from a demand point of view: An empirical analysis for andalusia. Tour Anal. 19(4):425-402014;

21. Fletcher J, Fyall A, Gilbert D, Wanhill S. Tourism: Principles and Practice 6th Edition. 7 p.2013.

22. García-Hernández M, de la Calle-Vaquero M, Yubero C. Cultural heritage and urban tourism: Historic city centres under pressure. Sustain. 9(8)2017;

23. Chin WL, Haddock-Fraser J, Hampton MP. Destination competitiveness: evidence from Bali. Curr Issues Tour. 20(12):1265-892017 Sep 10;

24. Jeuring JHG, Haartsen T. The challenge of proximity: the (un)attractiveness of near-home tourism destinations. Tour Geogr. 19(1):118-412017;

25. Tóth G, Dávid L. Tourism and accessibility: An integrated approach. Appl Geogr. 30(4):666-772010 Dec;

26. Bahar O, Kozak M. Advancing destination competitiveness research: Comparison between tourists and service providers. J Travel Tour Mark. 22(2):61-712007;
27. Roberts L, Hall D. Rural Tourism and Recreation: Principles to Practice. CABI Publishing; 2001.

28. Eichhorn V, Buhalis D. Chapter 3. Accessibility: A Key Objective for the Tourism Industry. In: Buhalis D, Darcy S, editors. Accessible Tourism. Bristol, Blue Ridge Summit: Multilingual Matters; p. 46-612010.

29. Vengesayi S, Mavondo FT, Reisinger Y. Tourism destination attractiveness: Attractions, facilities, and people as predictors. Tour Anal. 14(5):621-362009;

30. Schuckert M, Liu X, Law R. Hospitality and Tourism Online Reviews: Recent Trends and Future Directions. J Travel Tour Mark. 32(5):608-212015;

31. Sainaghi R, Baggio R. Complexity traits and dynamics of tourism destinations. Tour Manag. 63:368-822017

Dec 1;

32. Liao TF. Binary. In: Lewis-Beck MS, Bryman A, Liao TF, editors. The Sage Encyclopedia of Social Science Research Methods. SAGE Reference; 2004.

33. Jawa Timur. Peraturan Daerah Provinsi Jawa Timur Nomor 6 Tahun 2017 Tentang Rencana Induk Pembangunan Kepariwisataan Provinsi Jawa Timur Tahun 2017- 2032. 2017.

34. Disbudparpora. Potensi Pariwisata Kabupaten Ponorogo Tahun 2016. 2016.

35. Disbudparpora. Perkembangan Jumlah Wisatawan Tahun 2011-2015. 2016.

36. Cohen SA, Prayag G, Moital M. Consumer behaviour in tourism: Concepts, influences and opportunities. Vol. 17, Current Issues in Tourism. Routledge; $p$. 872-9092014.

37. Vada S, Prentice C, Scott N, Hsiao A. Positive psychology and tourist well-being: A systematic literature review. Tour Manag Perspect. 33(December 2019):1006312020; 